\title{
PENGARUH KEPUASAN KERJA TERHADAP TURNOVER INTENTION PADA CV SURYA NEDIKA ISABELLA
}

\author{
Candra Yudi Prasetyo ${ }^{1)}$, Sudarmiani ${ }^{2)}$ \\ Pendidikan Ekonomi FKIP UNIVERSITAS PGRI MADIUN \\ Cyudi92@gmail.com
}

\begin{abstract}
This study aims to determine the effect of job satisfaction on turnover intention of employees at the CV Nedika Isabella Kawedanan Magetan, to determine the turnover intention of employees at the CV Nedika Isabella Kawedanan Magetan, as well as to determine whether there is influence of job satisfaction on turnover intention on the $C V$ Surya Nedika Isabella Kawedanan Magetan. Determination of the sample in this study using the sample Nonprobability sampling technique of sampling Purposive Sampling that is as much as 70 employees. The data collection instrument uses a Likert scale questionnaire that has been tested and validated and validity and reliability. Data analysis using simple linear regression then t test. In releasing the data using the help of SPSS for windows version 22.0. pnenlitian results showed that job satisfaction has a negative effect on turnover intention on the CV Surya Nedika Isabella Kawedanan Magetan. Results of simple linear regression $Y=$ 69.919 - 0,228X, meaning that if the job satisfaction increased by $1 \%$, the turnover intention fell by 0.228. The results obtained Sighit value is 0.000 while Sigprob 0.05 which means there is rejection Ho. Job satisfaction affects turnover intention
\end{abstract}

Keywords: Job Satisfaction, Turnover Intention

\begin{abstract}
Abstrak
Penelitian ini bertujuan untuk mengetahui pengaruh kepuasan kerja terhadap turnover intention karyawan pada CV Surya Nedika Isabella Kawedanan Magetan, untuk mengetahui turnover intention karyawan pada CV Surya Nedika Isabella Kawedanan Magetan, serta untuk mengetahui ada tidaknya pengaruh kepuasan kerja terhadap turnover intention pada CV Surya Nedika Isabella Kawedanan Magetan. Penentuan sampel dalam penelitian ini menggunakan sampel Nonprobability sampling teknik pengambilan sampel Purposive Sampling yaitu sebanyak 70 orang karyawan. Instrumen pengumpulan data menggunakan angket skala likert yang telah diuji cobakan dan memenuhi syarat validitas dan reliabilitas. Analisis data menggunakan regresi linier sederhana kemudian dilakukan uji t. Dalam menganalisis data menggunakan bantuan program SPSS for windows versi 22.0. Hasil penelitian menunjukkan bahwa kepuasan kerja mempunyai pengaruh negatif terhadap turnover intention pada CV Surya Nedika Isabella Kawedanan Magetan. Hasil regresi linier sederhana diperoleh $\mathrm{Y}=69,919$ - 0,228X, artinya apabila kepuasan kerja meningkat $1 \%$ maka turnover intention turun sebesar 0,228. Hasil penelitian diperoleh nilai $\mathrm{Sig}_{\text {hit }}$ adalah 0,000 sedangkan $\operatorname{Sig}_{\text {prob }}$ 0,05 yang berarti ada penolakan Ho. Kepuasan kerja berpengaruh terhadap turnover intention.
\end{abstract}

Kata kunci: Kepuasan Kerja, Turnover Intention 


\section{PENDAHULUAN}

Sumber daya manusia merupakan mahkluk sosial yang menjadi aset utama didalam suatu perusahaan yang harus diperhatikan dan diberi kenyamanan saat bekerja, karena sumber daya manusia adalah pemeran tokoh utama dalam suatu perusahaan. Seorang karyawan akan menjadi perencana, pelaksana dan pengendali yang selalu berperan aktif dalam mewujudkan tujuan perusahaan dengan cara mereka bertugas, melaksanakan kewajiban atau tanggung jawab di suatu perusahaan.

Peningkatan kepuasan kerja karyawan akan menimbulkan suatu keadaan dimana karyawan tersebut semangat dan mempunyai motivasi yang tinggi dalam bekerja. Berbeda sebaliknya jika kepuasan kerja tidak dipenuhi karyawan akan sulit dalam melakukan sebuah pekerjaan.

Untuk mendukung penelitian ini peneliti membandingkan dengan penelitian sejenis lainnya yang diperoleh dari jurnal yang disusun dalam penelitian yang dilakukan oleh Muhammad Ainul Yaqin, (2013: 928). Menyimpulkan bahwa kepuasan kerja berpengaruh negatif signifikan terhadap turnover intention, hasil ini disebabkan oleh beberapa indikator kepuasan kerja seperti pekerjaan, gaji, moral, pengawasan dan rekan kerja memiliki tingkat kepuasan kerja pada kategori rendah.

Penelitian yang terdahulu juga dilakukan oleh Nita Ratna Sari, Moehammad So'oed Hakam dan Heru Susilo, (2015:7). Dalam penelitian ini ditarik kesimpulan bahwa kepuasan kerja karyawan pada pembayaran, kepuasan rekan kerja, kepuasan dalam bekerja, kepuasan promosi pada penyelia AJB Bumiputera 1912 Kantor Wilayah Jatim II/Malang adalah tinggi sedangkan tingkat turnover intentionnya adalah rendah.

Menurut Sentot Imam Wahjono (2015: 27) "Produktivitas, Kepuasan Kerja, Waktu, dan Proses belajar mempengaruhi Spesiali- sasi Pekerjaan, ketiga variabel tersebut juga memengaruhi perputaran karyawan".

Kepuasan kerja di dalam suatu perusahaan akan menjadi masalah yang menarik dan penting untuk dibahas karena mempunyai dampak yang cukup besar bagi individu, industri, maupun masyarakat. Bagi seorang karyawan atau individu akan memberikan dampak yang baik karena bisa meningkatkan kebahagiaan dan kesejahteraan hidup mereka.

Menurut Santoso (2012:136) “pekerja sering menghadapi pilihan apakah akan tetap tinggal pada pekerjaan lamanya atau akan pindah ke pekerjaan yang baru". Keinginan perpindahan seorang pekerja dari satu pekerjaan ke pekerjaan yang lain disebut sebagai Turnover Intention".

Pada era yang maju ini kita dituntut untuk selalu serba cekatan dan disiplin dalam bekerja, bekerja pada umumnya untuk memenuhi ekonomi baik perekonomian sendiri maupun perekonomian keluarga, dalam suatu pekerjaan yang dikerjakan haruslah sesuai dengan minat dan bakat seseorang, jika hal tersebut tidak tercukupi dengan baik akan timbullah ketidak puasan pada karyawan saat bekerja yang akan mengakibatkan terjadinya perpindahan kerja karyawan di suatu perusahaan yang akan berakibat buruk bagi keberlangsungan suatu perusahaan, menyikapi hal tersebut suatu perusahaan atau instansi terkait harus betulbetul memikirkan mengenai kesejahteraan karyawannya. CV Surya Nedika Isabella adalah perusahaan yang bergerak di bidang makanan dan minuman yang beralamatkan di RT. 5/RW. 2 Genengan, Kecamatan Kawedanan, Magetan.

Visi perusahaan, yaitu menjadi produsen consumer good yang terdepan dalam mutu produk dan mempertahankan kearifan lokal sedangkan misi perusahaan, yaitu mengembangkan wilayah pemasaran kapasitas produksi berkelanjutan, konsisten 
di dalam menjaga mutu produk memberdayakan sumber daya lokal sebagai kekuatan produk.

Produk-produk CV. Surya Nedika Isabella di antaranya adalah minuman kopi, rasa, teh hijau, asam jawa, es doger, nata dan air mineral. Ada juga snack yaitu snack bola dan snack krupuk. Dan yang terakhir adalah jelly, jelly drink mangga, orange, anggur, puding dan polos. Distributor area pemasaran produk perusahaan ada di Pulau Jawa, Madura, Bali, Nusa Tenggara Barat dan Kalimantan.

"Turnover intention adalah keinginan berpindah yang menggambarkan pikiran individu untuk keluar, mencari pekerjaan di tempat lain, serta keinginan meninggalkan organisasi” (Nita Ratna Sari dkk, 2015:3).

Pindah kerja (Turnover) adalah "pegawai berhenti dari suatu perusahaan atau organisasi dan pindah kerja ke perusahaan atau organisasi lainnya dengan alasan tertentu"(Wirawan, 2015:629).

Menurut R. Mathis dan J. H. Jackson (2009:125) jenis perputaran dikelompokkan menjadi 2 cara yang berbeda. Klasifikasi tersebut dapat dijelaskan sebagai berikut:

1. Perputaran secara tidak sukarela, pemecatan karena kinerja yang buruk dan pelanggaran peraturan kerja.

2. Sedangkan perputaran secara sukarela, karyawan meninggalkan perusahaan karenakeininannya sendiri

Menurut Rivai (Anggraeni, 2015) indikator yang perlu digunakan untuk mengetahui perputaran karyawan meliputi :

1. Komitmen organisasi, seorang karyawan yang mempunyai komitmen terhadap organisasi akan mempengaruhinya secara kuat untuk tetap bertahan di perusahaannya.

2. Peluang jangka panjang, dalam hal ini mengenai pandangan seseorang melihat masa depannya di perusahaan yang mereka tempati.
3. Meninggalkan perusahaan, namun juga berlaku sebaliknya.

4. Stress kerja, jika karyawan mengalami stress tinggi, maka cendenrung akan meninggalkan suatu perusahaan.

5. Keadilan, perlakuan secara adil bagi seluruh karyawan akan meneguhkan karyawan semakin loyal terhadap perusahaan dan akan tetap bertahan.

Menurut R. Mathis dan J. H. Jackson (2009:125) Turnover (perputaran) adalah "tingkat keluar masuk karyawan terjadi ketika karyawan meninggalkan organisasi dan harus digantikan". Menurut penelitian yang dilakukan oleh Ana Sri wahyuni (2014: 90) terdapat beberapa faktor eksternal Turnover Intention, yaitu:

1. Gaji/upah

2. Insentif

3. Sikap atasan

4. Dukungan tempat \& alat

5. Promosi jabatan

6. Peluang karier

Menurut Wirawan (2015:634) Turnover dapat menimbulkan keuntungan dan kerugian, yaitu:

1. Kerugian, Turnover dapat menimbulkan kerugian bagi perusahaan. Kerugian tersebut antara lain :

a. Kinerja perusahaan, Jika Turnover dilakukan oleh pegawai bertalenta yang memegang unit-unit kunci menentukan keberhasilan perusahaan mencapai tujuannya, akan mempengaruhi kinerja karyawan.

b. Biaya Turnover pegawai, Jika pegawai yang pindah kerja dan perlu diganti, perusahaan harus mengeluarkan biaya untuk merekrut pegawai. Biaya tersebut antara lain biaya rekrutmen dan seleksi.

2. Keuntungan

Turnover mempunyai potensi untuk menguntungkan perusahaan/ organisasi. Menurut C. Glebeek \& Eric 
H. Box (2002) (dalam Wirawan, 2015) mengemukakan keuntungan tersebut antara lain :

a. Perginya tenaga kerja yang relatif bergaji mahal, Jika perusahaan menggunakan sistem kompensasi berdasarkan senioritas atau jika premium untuk jaminan sosial berdasarkan umur maka biaya pegawai makin lama dan makin tua makin tinggi.

Jika kenaikan biaya tenaga kerja meningkat melampaui peningkatan produktivitas pegawai, pergantian tenaga kerja akan menjadi lebih menguntungkan.

b. Perginya tenaga kerja yang kurang produktif, Tenaga kerja yang kurang produktif adalah tenaga kerja yang sudah tua, fisik dan mentalnya menurun, atau karena tidak mampu mengikuti tekanan kerja dan perubahan lingkungan internal dan eksternal organisasi.

c. Pengakhiran kecocokan buruk, Hal ini terjadi jika produktivitas dan kinerja tidak banyak bergantung pada teknologi dan hubungan sosial dan ketrampilan kontekstual.

d. Inovasi, Turnoveri menciptakan kemungkinan untuk mengganti pegawai karena memungkinkan perusahaan untuk mengimpor jenis baru pengetahuan, ide-ide, pengalaman-pengalaman dan ketrampilan yang dibawa oleh pegawai baru.

Suatu reaksi emosional yang komplek, reaksi emosional ini merupakan akibat dari dorongan keinginan, tuntutan dan harapanharapan karyawan terhadap pekerjaan yang dihubungkan dengan realitas-realitas yang dirasakan karyawan, sehingga menimbulkan suatu bentuk reaksi emosional yang berwujud perasaan senang, perasaan puas ataupun perasaan tidak puas (Edy Sutrisno, 2011:74).
Sedangkan menurut Blum (dalam Edy Sutrisno 2011;77) banyak faktor yang mempengaruhi kepuasan kerja diantaranya adalah :

1. Faktor Individual, meliputi umur, kesehatan, watak, dan harapan.

2. Faktor sosial, meliputi hubungan kekeluargaan, pandangan pekerja, kebebasan politik, hubungan kemasyarakatan.

3. Faktor utama dalam pekerjaan, meliputi upah, pengawasan, ketentraman kerja, kondisi kerja, dan kesempatan untuk maju. Selain itu juga penghargaan terhadap kecakapan terhadap hubungan sosial di dalam pekerjaan, ketepatan dalam menyelesaikan konflik antar manusia, perasaan diperlukan adil dan baik yang menyangkut pribadi maupun tugas.

Beberapa faktor yang menimbulkan kepuasan kerja (Harold E. Burt dalam Sutrisno, 2015), yaitu:

1. Faktor hubungan antar karyawan

a. Hubungan antar manajer dengan karyawan

b. Faktor fisik dan kondisi kerja

c. Hubungan sosial di antara karyawan

d. Sugesti dari teman sekerja

2. Faktor individual, hubungan dengan:

a. Sikap orang terhadap pekerjaan

b. Usia orang dengan pekerjaan

c. Jenis kelamin

d. Faktor keadaan keluarga karyawan

e. Reaksi, meliputi pendidikan

Kepuasan kerja adalah sikap yang positif dari seorang pekerja atau karyawan meliputi perasaan dan tingkah laku terhadap pekerjannya melalui penilaian salah satu pekerjaan sebagai rasa menghargai dalam mencapai salah satu nilai-nilai penting pekerjaan.

Menurut Job Desciptive Index (Rivai dan Sagala, 2009;861) Indikator yang digunakan untuk mengukur kepuasan kerja seorang karyawan adalah: 
1. Isi Pekerjaan, Penampilan tugas pekerjaan yang aktual dan sebagai kontrol terhadap pekerjaan.

2. Supervisi.

3. Organisasi dan manajemen.

4. Kesempatan untuk maju

5. Gaji dan keuntungan dalam bidang finansial lainnya seperti adanya insentif

6. Rekan kerja dan,

7. Kondisi pekerjaan.

Menurut Anwar Prabu Mangkunegara $(2015 ; 120)$ di bawah ini diterangkan mengenai beberapa teori-teori tentang kepuasan kerja diantaranya adalah teori keseimbangan, teori perbedaan, teori pemenuhan kebutuhan, teori pandangan kelompok, teori pengharapan dan teori dua faktor Herzberg

1. Teori Keseimbangan (Equity theory), Wexley dan Yukl (1977) mengemukakan bahwa "input is anything of value that an employee percevies that he contributes to his job". Input adalah semua nilai yang diterima oleh pegawai yang dapat menunjang pelaksanaan kerja. Misalnya, pendidikan, pengalaman, skill, usaha, peralatan pribadi, jumlah jam kerja.

2. Teori Perbedaan (Discepancy theory), Teori ini pertama kali dipelopori oleh proter (dalam Mangkunegara, 2015). Ia berpendapat bahwa mengukur kepuasan dapat dilakukan dengan cara menghitung selisih antara apa yang seharusnya dengan kenyataan yang dirasakan pegawai.

3. Teori Pemenuhan Kebutuhan (Need Fulfillment Theory). Menurut toeori ini, kepuasan kerja pegawai bergantung pada terpenuhi atau tidaknya kebutuhan pegawai. Pegawai akan merasa lebih puas apabila ia mendapatkan apa yang dibutuhkannya.

4. Teori Pandangan Kelompok (Social Reference Group Theory), Menurut teori ini kepuasan kerja pegawai bukanlah bergantung pada pemenuhan kebutuhan saja, tetapi sangat bergantung terhadap pandangan dan pendapat kelompok yang oleh para pegawai dianggap sebagai kelompok acuan, kelompok acuan oleh tersebut dijadikan tolok ukur untuk menilai dirinya maupun lingkungannya. Jadi pegawai akan merasa puas apabila hasil kerjanya sesuai dengan minat dan kebutuhan yang diharapkan oleh kelompok acuan tersbut.

5. Teori Dua Faktor dari Herzberg, Penelitian Herzberg diadakan dengan melakukan wawancara terhadap subjek insinyur dan akuntan. Masing-masing subyek diminta menceritakan kejadian yang dialami oleh mereka baik yang menyenangkan (memberikan kepuasan) maupun yang tidak menyenangkan atau tidak memberi kepuasan.

6. Teori Pengharapan (Exceptancy Theory), Keirh Davis mengemukakan bahwa "Vroom explains that motivation is a product of how much one wants something and one's estimate of the probability that a certain will lead to it". Vroom menjelaskan bahwa motivasi seseorang merupakan suatu produk dari bagaimana seseorang menginginkan sesuatu, dan penaksiran seseorang memungkinkan aksi tertentu yang akan menuntunnya.

Menurut Anwar Prabu Mangkunegara (2015:126) mengukur kepuasan kerja dapat digunakan skala indeks deskripsi jabatan, skala kepuasan kerja berdasarkan eksappresi wajah, dan kuesioner kepuasan kerja minnesota. Pengukuran kepuasan kerja dapat dijelaskan sebagai berikut:

1. Pengukuran kepuasan kerja dengan skala indeks deskripsi jabatan. Skala ini dikembangkan oleh Smith, Kendall, dan Hulin pada tahun 1969. Dalam penggunaannya pegawai ditanya mengenai pekerjaan maupun jabatannya yang dirasakan sangat baik dan sangat buruk dalam skala mengukur sikap dari lima 
area, yaitu kerja pengawasan, upah, promosi dan co-worker.

2. Pengukuran kepuasan kerja dengan berdasarkan ekspresi wajah. Mengukur kepuasan kerja ini dikembangkan oleh kunin pada tahun 1955. Skala ini terdiri dari seri gambar wajah-wajah orang mulai dari sangat gembira, gembira, netral, cemberut dan sangat cemberut.

3. Pengukuran kepuasan kerja dengan kuesioner minnestoa. Pengukuran kepuasan kerja ini dikembangkan oleh Weiss, Dawis dan England pada tahun 1967. Skala ini terdiri dari pekerjaan yang dirasakan sangat tidak puas, tidak puas, netral, memuaskan. Pegawai diminta memilih satu alternatif jawaban yang sesuai dengan kondisi pekerjaannya.

\section{METODE PENELITIAN}

Penelitian ini mengambil tempat di CV Surya Nedika Isabella yang beralamatkan di Genengan RT. 05 RW. 02 Kawedanan, Magetan, Jawa Timur. Alasan pemilihan CV tersebut dikarenakan karyawan di CV Surya Nedika Isabella mempunyai tingkat kepuasan kerja yang berbeda-beda. Tingkat kepuasan tersebut yang nantinya akan menentukan Turnover Intention. Sebelum melakukan sebuah penelitian, perlu dibuat rencana penelitian atau desain penelitian yang sesuai masalah. Moh. Nazir (2011:84) mengatakan bahwa "Desain penelitian adalah semua proses yang diperlukan dalam perencanaan dan pelaksanaan penelitian".

Desain penelitian yang digunakan dalam penelitian ini adalah desain penelitian konklusif. Menurut Juliansyah Noor (2011: 110) "desain penelitian konklusif yaitu jenis penelitian yang bertujuan untuk menguji hipotesis. Penelitian konklusif didesain untuk membantu pengambil keputusan dalam menentukan, mengevaluasi, dan memilih alternatif terbaik dalam memecahkan suatu masalah".
Metode penelitian yang digunakan dalam penelitian ini adalah metode kuantitatif. Menurut Sugiyono (2010: 14) "Metode Kuantitatif dapat diartikan sebagai metode penelitian yang berlandaskan pada filsafat positivisme, digunakan untuk meneliti pada populasi atau sampel tertentu, teknik pengambilan sampel pada umumnya dilakukan secara random, pengumpulan data menggunakan instrument penelitian, analisis data bersifat kuantitatif atau statistik, dengan tujuan untuk menguji hipotesis yang telah ditetapkan".

Untuk memperoleh hasil yang maksimal dalam penelitian diperlukan kejelasan tentang variabel penelitian. "Variabel penelitian adalah suatu atribut, nilai-nilai, sifat dari objek-objek, individu dan atau kegiatan yang mempunyai banyak variasi antara satu dengan lainnya yang telah ditentukan oleh peneliti untuk dipelajari dan dicari informasinya serta ditarik kesimpulannya dalam suatu penelitian" (Hamid Darmadi, 2014: 14).

Suharsimi Arikunto (2013: 173), mengatakan bahwa "populasi adalah keseluruhan subjek penelitian”. Sehingga dapat disimpulkan bahwa populasi merupakan keseluruhan subjek/objek yang dapat diteliti untuk dapat memperoleh suatu informasi dan ditarik kesimpulannya.

Dalam penelitian ini yang menjadi populasi adalah karyawan atau tenaga kerja pada CV Surya Nedika Isabella Kawedanan Magetan yang berjumlah 342 orang karyawan.

Suharsimi Arikunto (2013: 174), “jika kita hanya akan meneliti sebagian dari populasi, maka penelitian tersebut disebut penelitian sampel. Sampel adalah sebagian atau wakil populasi yang diteliti”.

Menurut Sugiyono (2010: 118), "sampel adalah bagian dari jumlah dan karakteristik yang dimiliki oleh populasi tersebut. Bila populasi besar, dan peneliti 
tidak mungkin mempelajari semua yang ada pada populasi, misalnya karena keterbatasan dana, tenaga dan waktu, maka peneliti dapat menggunakan sampel yang diambil dari populasi tersebut. Untuk itu sampel yang diambil dari populasi harus betul-betul representatif(mewakili)".

Berdasarkan penjelasan di atas maka dapat disimpulkan bahwa sampel adalah wakil dari anggota populasi untuk penelitian. Sampel pada penelitian ini dihitung menggunakan teknik purposive sampling. Purposive sampling adalah "teknik pengambilan sampel sumber data dengan pertimbangan tertentu, pertimbangan tertentu ini misalnya orang tersebut dianggap paling tahu tentang apa yang kita harapkan, atau mungkin dia sebagai penguasa sehingga akan memudahkan peneliti menjelajahi objek yang diteliti" (Sugiyono, 2010:300). Adapun sampel dalam penelitian ini adalah karyawan CV Surya Nedika Isabella yaitu 70 orang karyawan. Dengan alasan kriteria sampel yang diperoleh benar-benar sesuai dengan apa yang diharapkan $\mathrm{CV}$ dan juga peneliti.

Dengan demikian sesuai dengan sampel jenuh maka diperoleh karyawan yang diteliti adalah sejumlah 70 orang karyawan/tenaga kerja.

Sampel pada penelitian ini dihitung menggunakan teknik purposive sampling.

1. Angket

Angket yang digunakan dalam penelitian ini adalah kuesioner tertutup. Menurut Syofian Siregar (2013: 44) "kuesioner tertutup merupakan pertanyaan-pertanyaan yang diberikan kepada responden sudah dalam bentuk pilihan ganda. Jadi, kuesioner jenis ini responden tidak diberi kesempatan untuk mengeluarkan pendapat". Dengan alasan agar tidak merepotkan dan membebani para karyawan atau tenaga kerja pada $\mathrm{CV}$ Surya Nedika Isabella Kawedanan Magetan dan cara pengisian angket pun tidak membutuhkan waktu yang lama. Demikian dalam penelitian ini jumlah soal angket (kuesioner) yang diberikan kepada karyawan adalah 24 butir soal yang terbagi dalam dua variabel yang akan diteliti yaitu angket (kuesioner) Kepuasan kerja karyawan (Variabel bebas) yang berjumlah 10 butir soal dan angket (kuesioner) perputaran karyawan (Variabel terikat) yang berjumlah 15 butir soal.

2. Observasi

Teknik ini menuntut adanya pengamatan dari peneliti baik secara langsung maupun tidak langsung terhadap objek penelitian" ( Juliansyah Noor (2011: 140). Tujuan penelitian menggunakan metode observasi ini adalah ingin mengetahui suatu objek atau peristiwa secara detail terhadap kondisi lingkungan objek penelitian yang mendukung kegiatan penelitian sehingga dapat dilakukan dengan cara peninjauan secara langsung pada CV Surya Nedika Isabella Kawedanan Magetan.

3. Dokumentasi

Menurut Juliansyah Noor (2011: 141), "Sejumlah besar fakta dan data tersimpan dalam bahan yang berbentuk dokumentasi. Sebagian besar data yang tersedia yaitu berbentuk surat, catatan harian, cendera mata, laporan, artefak, dan foto".

Dalam penelitian yang dilakukan pada CV Surya Nedika Isabella Kawedanan Magetan alat yang digunakan berupa kamera foto dan buku catatan. Pengumpulan data dilakukan dengan cara peninjauan secara langsung terhadap karyawan atau tenaga kerja pada perusahaan Surya Nedika Isabella Kawedanan Magetan yang nantinya peneliti menyerahkan angket kepada responden/ karyawan untuk mengisi angket tersebut lalu peneliti mendokumentasikannya dengan cara memotret responden. 
1. Uji Prasarat atau Instrumen

a. Uji Validitas

"Validitas/kesagihan adalah suatu indeks yang menunjukkan alat ukur tesebut benar-benar mengukur apa yang diukur. Untuk mengetahui apakah kesioner yang disusun tersebut itu valid/sahih, maka perlu diuji dengan uji korelasi antara skor (nilai) tiap-tiap butir pertanyaan dengan skor total kuesioner tersebut" (Juliansyah Noor, 2011: 132). Dalam uji validitas digunakan korelasi product moment korelasi berguna untuk menentukan suatu besaran yang menyatakan bagaimana kuat hubungan suatu variabel dengan variabel lain". Uji validitas bertujuan untuk mengetahui apakah keadaan responden yang sebenarnya.

b. Uji Reliabilitas

Uji reliabilitas yang digunakan dalam penelitian ini menggunakan metode Alpha Cronbach.

"Reliabilitas merupakan keandalan pengukuran dengan menggunakan Alfa Cronbach adalah koefisien keandalan yang menunjukkan seberapa baiknya item/butir dalam suatu kumpulan secara positif berkorelasi satu sama lain" (Juliansyah Noor, 2011: 165).

\section{Uji Asumsi Klasik}

Menurut Latan dan Temalagi (2013: 56) mendefinisikan "pengujian terhadap asumsiasumsi regresi linear bertujuan untuk menghindari munculnya bisa dalam analisis data serta untuk menghindari kesalahan spesifikasi (misspecification) model regresi yang digunakan. Uji asumsi yang digunakan adalah normalitas. Pengujian terhadap asumsi klasik normalitas bertujuan untuk mengetahui apakah residual data dari model regresi linear memiliki distribusi normal ataukah tidak".

Kriteria Uji signifikansi t yang digunakan yaitu:
"Pada uji statistic One Sample Kolmogorov-Smirnov Test, jika didapat nilai signifikan $>0,05$, maka dapat disimpulkan bahwa data terdistribusi normal secara multivariate". (Latan dan Temalagi, 2013: 57)

Menurut Juliansyah Noor (2011: 174), "Uji Normalitas dilakukan untuk mengetahui apakah data yang diambil berasal dari populasi yang berdistribusi normal atau tidak".

3. Uji Hipotesis atau Analisis Data

Untuk uji hipotesis menggunakan teknik analisis regresi linier sederhana menggunakan koefisien determinan dan uji t. Koefisien determinasi digunakan untuk menguji pengaruh antara variabel satu dengan yang lain. Variabel yang dimaksud adalah variabel independen yaitu Kepuasan Kerja (X) dan variabel dependen yaitu Turnover Intention (Y). Sedangkan uji t untuk mengetahui apakah variabel bebas secara individu mempunyai pengaruh yang signifikan terhadap variabel terikat.

\section{HASIL DAN PEMBAHASAN}

Dideskripsikan bahwa Kepuasan Kerja dengan jumlah data (N) sebanyak 70 responden mempunyai deskripsi data sebagai berikut: (a) Jumlah skor total sebesar 2349; (b) Nilai rata-rata hitung (mean) sebasar 33,56; (c) Median sebesar 35,00; (d) Modus sebesar 35; (e) Standar deviasi sebesar 4,702; (f) Nilai minimum sebesar 23; (g) Nilai maximum sebesar 42 .

Hasil analisis deskriptif Kepuasan Kerja yang diolah dari 70 responden yang menyatakan sebanyak 47 Karyawan atau $67 \%$ di atas rata-rata dan sebanyak 23 karyawan atau 33\% di bawah rata-rata. Dengan demikian Kepuasan Kerja pada CV Surya Nedika Isabella cukup baik.

Dideskripsikan bahwa Turnover Intention dengan jumlah data $(\mathrm{N})$ sebanyak 70 responden mempunyai deskripsi data sebagai berikut: (a) Jumlah skor total sebesar 
4359; (b) Nilai rata-rata hitung (mean) sebesar 62,27; (c) Median sebesar 60,50; (d) Modus sebesar 72; (e) Standar deviasi sebesar 7,678; (f) Nilai minimum sebesar 49; (g) Nilai maximum sebesar 75 .

Hasil analisis deskriptif Turnover Intention yang diolah dari 70 responden yang menyatakan sebanyak 25 karyawan atau $36 \%$ di atas rata-rata dan sebanyak 45 karyawan atau $64 \%$ di bawah rata-rata. Dengan demikian Turnover Intention pada CV Surya Nedika Isabella Kawedanan Magetan rendah.

\section{Hasil Uji Validitas}

Hasil dari uji validitas angket Kepuasan Kerja terhadap Karyawan CV Surya Nedika Isabella sebanyak 20 karyawan. Dari 10 soal Kepuasan Kerja yang diuji hasilnya semua valid. Hasil dari uji validitas angket Turnover Intention diuji kepada karyawan CV Surya Nedika Isabella. Dari 15 soal Turnover Intention yang diuji hasilnya semua valid (koefisien di atas 0,423) dapat dipergunakan oleh peneliti sebagai instrumen penelitian.

\section{Hasil Uji Reliabilitas}

Uji Reliabilitas pada penelitian ini dilakukan dengan menggunakan rumus alpha cronbach. Juliansyah Noor (2011: 165), "kriteria suatu instrumen penelitian jika nilai alpha > 0,6 disebut reliabel". Hasil uji reliabilitas variabel Kepuasan kerja dan Turnover Intention adalah 0,603 dan 0,761 maka semua dinyatakan reliabel.

\section{Hasil Uji Asumsi Klasik}

Menurut Latan dan Temalagi (2013: 56) mendefinisikan "pengujian terhadap asumsiasumsi regresi linear bertujuan untuk menghindari munculnya bisa dalam analisis data serta untuk menghindari kesalahan spesifikasi (misspecification) model regresi yang digunakan. Uji asumsi yang digunakan adalah normalitas. Pengujian terhadap asumsi klasik normalitas bertujuan untuk mengetahui apakah residual data dari model regresi linear memiliki distribusi normal ataukah tidak".

Uji Normalitas bertujuan untuk meng- uji apakah dalam model regresi variabel pengganggu atau residu memiliki distribusi normal. Apabila data berdistribusi normal, maka dapat digunakan uji statistik berjenis parametrik. Syarat analisis parametrik yaitu distribusi data harus normal. Pengujian menggunakan uji Kolmogorov-Smirnov (Analisis Explore) untuk mengetahui apakah distribusi data pada tiap-tiap variabel normal atau tidak. Hasil uji normalitas yang terdapat di atas bahwa nilai Assymp Sig sebesar 0.032 lebih besar dari 0.05 , dengan demikian dapat disimpulkan bahwa data yang akan dianalisis terdistribusi normal.

\section{Uji Regresi Linier Sederhana}

Dalam penelitian pengaruh kepuasan kerja terhadap Turnover Intention, analisis yang digunakan adalah dengan menggunakan regresi linier sederhana. Juliansyah Noor (2011: 179) "mengemukakan analisis regresi sederhana digunakan untuk mengetahui pengaruh dari variabel bebas terhadap variabel terikat atau dengan kata lain untuk mengetahui seberapa jauh perubahan variabel bebas dalam mempengaruhi variabel terikat".

Uji Regresi Linier sederhana diperoleh persamaan $\mathrm{Y}=69,919-0,228 \mathrm{X}$. Konstanta sama dengan 69,919, artinya apabila variabel Kepuasan Kerja bernilai tetap atau konstant, maka besarnya Turnover Intention adalah 69,919.

\section{Koefisien Determinasi (R-Square)}

Dari hasil pengolahan data dengan menggunakan program SPSS versi 22.0 dapat diketahui bahwa koefisien determinasi (Adjusted R-Square) yang diperoleh sebesar 0,015. Yang artinya, Kepuasan Kerja berpengaruh terhadap Turnover Intention pada CV Surya Nedika Isabella sebesar 1,5\% sedangkan sisanya sebesar 98,5\% dipengaruhi oleh faktor lain yang tidak diteliti.

\section{Uji T}

Menurut G. Amin Silalahi (2003: 86), "Uji t yaitu analisis untuk mengetahui apakah variabel bebas secara individual mempunyai 
pengaruh yang signifikan terhadap variabel terikat".

Kriteria Uji signifikansi t yang digunakan yaitu:

"Jika nilai signifikansi yang dihasilkan uji t $\mathrm{P}<0.05$, maka dapat disimpulkan bahwa secara parsial variabel independen berpengaruh signifikan terhadap variabel dependen" (Hengky Latan dan Selva Temalagi, 2013: 81).

Koefisien regresi atau uji $\mathrm{t}$ diperoleh nilai $\mathrm{Sig}_{\text {hit }}$ adalah 0,000 sedangkan $\operatorname{Sig}_{\text {prob }} 0,05$. Hal ini berarti bahwa $\operatorname{Sig}_{\text {hit }} \leq \operatorname{Sig}_{\text {prob }}(0,000 \leq$ $0,05)$. Atas dasar uji t tersebut dapat disimpulkan tolak Ho, Ha diterima, antara kepuasan kerja terhadap keinginan untuk pindah pada CV Surya Nedika Isabella.

\section{PENUTUP}

\section{Simpulan}

Simpulan dari penelitian mengenai pengaruh Kepuasan Kerja terhadap Keinginan untuk pindah pada CV Surya Nedika Isabella adalah sebagai berikut:

1. Karyawan yang bekerja pada CV Surya Nedika Isabella mempunyai tingkat kepuasan kerja yang cukup baik. Hal ini dapat dilihat dari hasil analisis yang disebar melalui kuesioner dengan jumlah data $(\mathrm{N})$ sebanyak 70 orang karyawan, yang berada di atas nilai rata-rata sebanyak 47 karyawan atau sebesar (67\%) sedangkan skor di bawah nilai rata-rata sebanyak 23 pelanggan atau sebesar $33 \%$.

2. Sedangkan turnover intention pada CV Surya Nedika Isabella relatif rendah. Hal ini dapat dilihat dari hasil analisis angket yang disebar melalui kuesioner dengan jumlah data $(\mathrm{N})$ sebanyak 70 orang karyawan, yang berada di atas nilai ratarata sebanyak 25 karyawan atau 36\% sedangkan yang berada di bawah nilai rata-rata sebanyak 45 karyawan atau sebesar 64\%.

3. Kepuasan Kerja mempunyai pengaruh terhadap keinginan pindah karyawan pada CV Surya Nedika Isabella. Hal ini terbukti dari hasil analisis uji t yaitu diperoleh niali $\mathrm{Sig}_{\text {hit }}$ 0,000 sedangkan $\mathrm{Sig}_{\text {prob }}$ 0,05. Hal ini berarti $\operatorname{Sig}_{\text {hit }} \leq \operatorname{Sig}_{\text {prob }}(0,000 \leq 0,05)$. Dengan demikian Ho ditolak, artinya ada beda pengaruh kepuasan kerja terhadap turnover intention pada CV Surya Nedika Isabella.

\section{Saran}

Dalam penelitian ini penulis memberikan saran yang mungkin dapat menjadi bahan pertimbangan bagi CV Surya Nedika Isabella. Adapun saran-saran tersebut di antaranya:

1. Bagi CV Surya Nedika Isabella

Pemberian kepuasan kerja terhadap karyawan sangatlah penting. Hal tersebut nantinya akan mendorong karyawan untuk semangat dan mempunyai motivasi saat mereka bekerja. Dengan kepuasan kerja yang cukup karyawan akan merasa betah dengan pekerjaannya dan keinginan untuk pindah pun menjadi rendah.

2. Bagi karyawan

Saat karyawan bekerja tentunya harus mempunyai semangat dan keinginan yang kuat sehingga dalam bekerja karyawan bisa bekerja secara maksimal dan memperoleh suatu kepuasan kerja yang diinginkan oleh karyawan tersebut. Sehingga kepuasan kerja akan menurunkan keinginan untuk pindah dari perusahaan.

3. Bagi Peneliti Selanjutnya

Diharapkan untuk penelitian selanjutnya mampu menerapkan ilmu yang didapatkan dalam penelitian dan peneliti dapat menambah variabel bebas (X), karena selain Kepuasan kerja masih banyak faktor-faktor lain yang dapat mempengaruhi keinginan untuk pindah karyawan terhadap suatu perusahaan. 
4. Bagi lembaga UNIVERSITAS PGRI MADIUN

Dengan penelitian ini diharapkan dapat memperoleh wawasan dan pengetahuan yang luas serta dapat dijadikan bahan referensi bagi penelitian selanjutnya di perpustakaan.

\section{DAFTAR PUSTAKA}

Arikunto, Suharsimi. 2010. Prosedur Penelitian. Jakarta. PT Rineka Cipta.

Darmadi, Hamid. 2014. Metode Penelitian Pendidikan dan Sosial. Bandung. Alfabeta.

Latan, Hengki dan Selva Temalagi. 2013. Analisis Multivariate Teknik dan Aplikasi menggunakan Program IBM SPSS 20.0. Bandung. Alfabeta.

Lusia, Sinta A. 2015. Pengaruh Produktivitas Efisiensi, Kepuasan Kerja terhadap Perputaran Karyawan Bagian Marketing. Jurnal Ilmu dan Riset Manajemen. Volume 4.

Mangkunegara, Anwar Prabu. 2015. Manajemen Sumber daya Manusia Perusahaan. Bandung. PT Remaja Rosdakarya.

Mathis dan Jackson. 2009. Human Resource Management. Jakarta. Salemba Empat.

Nazir, Moh. 2011. Metode Penelitian. Bogor. Ghalia Indonesia.

Nita, Moehammad dkk. 2015. Pengaruh Kepuasan Kerja Terhadap Turnover
Intention. Jurnal Administrasi Bisnis. Volume 27.

Noor, Juliansyah. 2011. Metodologi Penelitian. Jakarta. Kencana Prenada Media Group.

Rivai, Sagala. 2009. Manajemen Sumber Daya Manusia untuk Perusahaan. Jakarta. PT Raja Grafindo.

Santoso, R. P. 2012. Ekonomi Sumber Daya Manusia dan Ketenagakerjaan. Yogyakarta. UPP STIM YKPN.

Sugiyono. 2010. Metode Penelitian Pendidikan. Bandung. Alfabeta.

Sutrisno, E. 2011. Manajemen Sumber Daya Manusia. Jakarta. Kencana Prenada Media Group.

Wahjono, Sentot Imam. 2015. Manajemen Sumber Daya Manusia. Jakarta. Salemba Empat.

Wirawan. 2015. Manajemen Sumber Daya Manusia Indonesia. Jakarta. PT Raja Grafindo Persada.

Yaqin, Muhammad Ainul. 2013. Pengaruh Kepuasan Kerja dan Komitmen Organisasi terhadap Turnover Intention Karyawan KJPP Toha, Okky, Heru \& Rekan Cabang Surabaya. Jurnal Ilmu Manajemen. Vol. 1.

Yusuf, Burhanudin. 2015. Manajemen Sumber Daya Manusia dan Lembaga Keuangan Syariah. Jakarta. PT Raja Grafindo Persada. 